\title{
Implementing Technology in Teaching French Through Instagram
}

\author{
$1^{\text {st }}$ Evi Eviyanti ${ }^{1}, 2^{\text {nd }}$ Irwandy $^{2}, 3^{\text {rd }}$ Rabiah Adawi ${ }^{3}$ \\ \{eviko65@gmail.com ${ }^{1}$, irwandymanday@gmail.com², rabiahfbs@unimed.ac.id ${ }^{3}$ \} \\ Department of French Language Education, Universitas Negeri Medan, Indonesia ${ }^{1,2,3}$
}

\begin{abstract}
In 2020, internet-based learning activities have been widely implemented in the field of education due to the Covid-19 pandemic in the world. All schools and colleges responded by carrying out learning from home, through online learning with the use of information technology. The e-learning that has been done by teachers during WFH has not been able to motivate students to learn French subjects. One of the most popular social media is Instagram. The presence of Instagram social media among teenagers is an interesting phenomenon. Teachers can share subject matter and exercises in the form of images, videos, and audio to students through Instagram media. The use of Instagram as a learning medium is a new phenomenon in the use of social media.
\end{abstract}

Keywords: social media, French, Instagram.

\section{Introduction}

Advances in information and communication technology have brought such a huge impact on the world of education. Currently, teachers are required to master various things related to science and technology to create interesting and easy-to-understand learning for students. In this case, the learning system has also changed, from conventional to modern learning systems. This modern learning system has given rise to a variety of learning media based on ICT (Information and communication Technology), one of which is a computer with an internet network.

In 2020, internet-based learning activities have been widely implemented in the field of education, from elementary to university levels due to the Covid-19 pandemic in the world. This condition requires physical distancing to break the chain of the spread of Covid-19. All schools and colleges responded by carrying out learning from home, through online learning with the use of information technology. Information technology has a role in the world of education to produce various types of learning programs that are very innovative and complex. One of the learning programs that use the internet is e-Learning.

In the 21 st century, several teachers, including teachers of French subjects, have tried to adapt to the development of information technology, especially those related to the world of education. French is one of the specialization subjects studied by students in grades X, XI, and XII in SHS/VHS Senior High School/Vocational High School.

E-learning is used as a learning tool that uses several applications or utilizes the use of internet technology to facilitate learning in the millennial era. The use of e-learning in the 2013 curriculum is carried out to keep up with technological developments in the 21 st century. 
E-learning is a combination of two words electronic and learning which means electronic learning [1]. E-learning or electronic learning was first introduced by the University of Illinois at Urbania-Campaign using a computer-assisted instruction system and a computer called Plato.

E-learning at a distance that uses computer technology (usually the Internet). E-learning enables employees to learn at their work computers without traveling to a classroom. Elearning can be a scheduled session with an instructor and other students, or it can be an ondemand course that the employee can take for self-directed learning at a time when it's convenient [2].

Based on some of the opinions above, e-learning is an internet application that can connect teachers and students in online classes.

Learning media has an important role to achieve learning objectives. The use of various learning media in addition to increasing learning motivation students can also make learning more meaningful. Currently, the world is entering an era industrial revolution 4.0. All human activities also intersect with digital platforms including the world of education. In the current era, in general, students have used smart devices, and as educators must be able to take advantage of these opportunities in teaching and learning activities. Internet technology that is most in the spotlight is the development of social media Facebook, Twitter, Line, Pinterest, and Instagram.

One application in smart devices that can be used in learning is Instagram. Instagram social media is one of the most potential sites because this site focuses on image and video media. Through pictures and videos, it is hoped that students will be more interested in learning French. In addition, Instagram has become a very popular application among students. Instagram can not only be used in face-to-face teaching and learning activities, but also by blended learning.

Social media is a medium on the internet that allows users to represent themselves and interact, work together, share, communicate with other users, and form virtual social bonds [3]. One of the most popular social media is Instagram.

Kevin Systrom as CEO and Instagram co-founder through the official website Instagram.com explained that Instagram is a community of more than 300 million people who every day share moments through images and videos on the Instagram service. Instagram focuses on the simplicity and creativity of users in utilizing Instagram's social media. Instagram has become a medium for telling everyone's visual activities.

Application Instagram can be downloaded for free on the Apple App Store and Google PlayStore. The idea of developing Instagram social media is that everyone likes to see interesting pictures through their respective Instagram social media. Therefore, teachers can share subject matter and exercises in the form of images, videos, and audio to students through Instagram media. The use of Instagram as a learning medium is a new phenomenon in the use of social media.

\section{Theory}

\subsection{Teaching French Using Instagram}

French is one of the languages used officially in various world institutions, such as; United Nations, European Union, NATO, as well as in various official world forums, such as; 
Non-Aligned Summit and Olympics. French teaching in high school covers four language skills: listening, speaking, reading, and writing which are integrated into French subjects. Based on the 2013 Curriculum French Language Subject Syllabus for class X, the materials taught include saluer et prendre congé, se présenter, heure,jour, date. mois, année, présenter son identité, des choses et des lieux publics, caractères de personnes et de choses, instructions, signes, panneaux, and paroles $d$ 'une chanson [4]. These materials are divided into odd semesters and even semesters. In odd semesters, students will study four learning topics. : 1) Saluer et prendre congé . Students will learn about greeting or greeting teachers, classmates, and elders. 2) Se présenter, students will learn about introducing themselves. 3) Heure,jour, date. mois, année , students will learn about stating the hour, date, day, month, and year in French, 4) présenter son identité, des choses et des lieux publics, students will learn about mentioning buildings or public places. After studying French in high school, students are expected to be able to use a variety of social linguistic functions to communicate both orally and in writing in simple situations equivalent to DELF (Diplôme d'Études en langue Française) A1 according to the curriculum which refers to the Common Reference for European Languages (Cadre Européen Commun de Référence pour les Langues /CECRL).

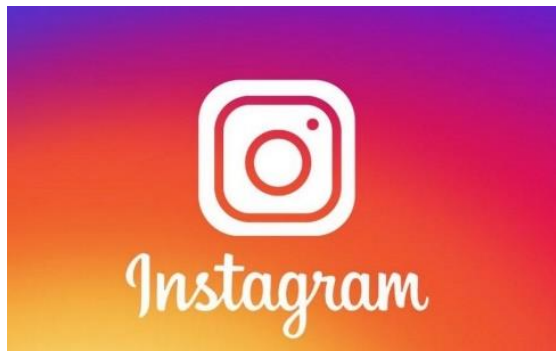

Fig. 1. Instagram app on google play store.

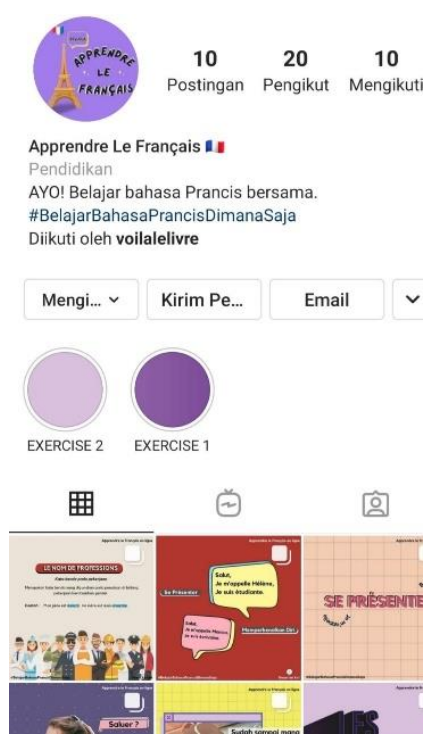

Fig. 2. Instagram account 'Apprendre Le Français_enligne'. 
Other classroom Instagram usage activities. The activities include making kids play a role and imag-ining how a famous person in history used instagram, imagining a beloved character, making the stu-dents go hunting scavengers, recording steps in a science experiment and even sharing reading ad-vice [5]. All in all, many academics think that Instagram can offer language learning opportunities. I want to construct exercises from the themes given above through Instagram into four linguistic skills.

Teachers are urged to build a teacher account before using Instagram in classroom activities. It is a separate account for dealing exclusively with students. The user name used on Instagram should also be considered by teachers. The professional, straight forward and familiar username for the pu-pils is the teacher. Le Français communicates the instructional aspect of the page and is easy to find for students. Teachers should likewise keep their accounts private (for students solely as disciples and to prevent unconnected followers). It can also distribute beneficial information in French learning through the teacher's Instagram account. Teachers can publish anything that can lead students to effi-ciently learn the language. Teachers can also offer other Instagram sources and information. Many different persons can support teachers by posting free le français resources.

One basic reason to use social media is it is familiar to almost all students. It also doesn't cost and require minimal training. Social media allows students to access an enormous variety of learning materials in most cases free of charge. Thus, social media has enough capacity for a good official education matching the social contexts of learning and promoting critical thinking in learners [6].

Instagram can be used in learning is a new phenomenon found in the use of social media. Instagram has features to share, namely images and videos. The facility will be utilized and shaped in such a way that it becomes an attractive feed design as a learning medium. Through pictures and videos, it is hoped that students will be interested in learning French. The teachers can use the facilities available from Instagram to convey assignments that are done at home and share information about the subject matter in attractive image visualizations [7].

Instagram can help develop a socially connected learning network in schools. Instagram is mainly associated with similar and remarkable capacities which Instagram users do not underestimate.

Instagram is a typically used online networking channel for young students who desire to use suc-cessfully Instagram for language learning [8].

Following a teacher account, teachers are recommended to build a private Instagram account in the classroom which is used exclusively for instruction. This private Instagram may simply be utilized to control students and connect students and other members of the graduate team. With the class account registration, students can send the account a direct message, knowing it is for them. Once an account has been established, teachers can construct several activities via this platform. Also discusses Instagram language learning activities [9]. The activity includes students taking field trips, making picture stories and essays based on curriculum goals, and participating in Instagram through one uniform hashtag. Points out that Instagram may also be used to implement a number of languages classroom activities, such as narrative, grammatical activity by taking pictures, playing roles, reading, speaking activities via videos, etc. In terms of language acquisition. Instagram therefore addresses four language skills in and outside the classroom [10].

Here are several activities that might encourage students in four main skills to learn French : 
Speaking activities. Learning activities to improve students' French-speaking skills that can be carried out by teachers using Instagram media, for example (1) the teacher uploads a dialogue about the material "Salutation" Then the teacher gives the task to the students to make a dialogue about "Salutation" (2-3 people) and they have to play a role according to the theme of the dialogue. The dialogues of these students must be recorded (video) and the recordings uploaded to their Instagram accounts. So that the teacher can listen and assess the speaking ability of each student (pronunciation, vocabulary, grammar, fluency, and understanding), (2) The teacher uploads photos of daily activities carried out by a child. Then the teacher gives practice to students to verbally tell the daily activities, (3) The teacher gives assignments to students to upload photos of activities carried out on the weekend to their Instagram accounts. Furthermore, each student must tell each other the activities of the weekend.

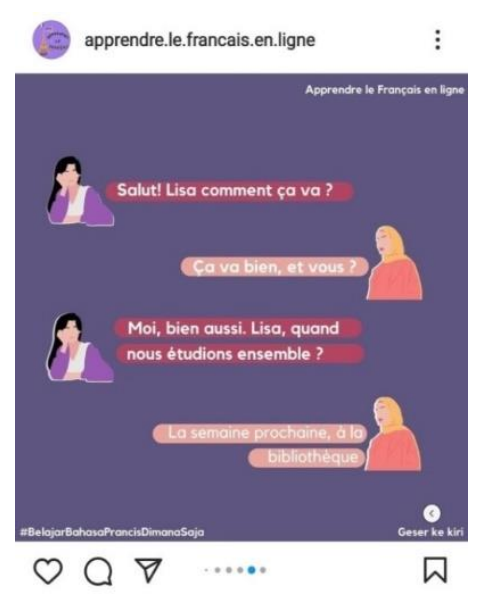

Fig. 3. Conversation.

Students are asked to use the hashtag, which others have not used earlier. Students can also be as-signed to design a countdown sentence based on an Instagram picture. A hashtag will offer an over-view of what the subject of their presentation is. It is helpful to provide a photo series to display and structurally develop the narrative text.

They did not want to find images. She also remarked that easy access by the students to images that have been filtered using Instagram focuses mainly on content than on the language employed.

When sharing their experience on vacation, students were proud to share their photos. Finally, teachers can also encourage students to study each of their friends' films and say something about them. This is fun for the students. You may directly examine your video and repair errors. Stu-dents can publish photographs or videos on Instagram that can be commented on by the spectators. Teachers can create interesting classroom exercises with the use of Instagram.

Reading activities. In reading learning activities, for example, teachers can upload simple text or illustrated stories (comics) to Instagram with a holiday theme. Next, the teacher gives some questions about the holiday that must be answered by each student. 
Writing activities. The difficulty of discovering the idea is one of the students' written problems. An inspiration fairy can be deployed by Instagram to help scholars write promptly. Teachers can publish a fascinat-ing image, comic, and encourage students in their comments to write a descriptive text. The photo might help students to come up with ideas for what to write. It will be difficult to encourage students to compose their titles using specified sorts of sentences, language components, and current terms. The teachers will now be able to reward the most excellent title.

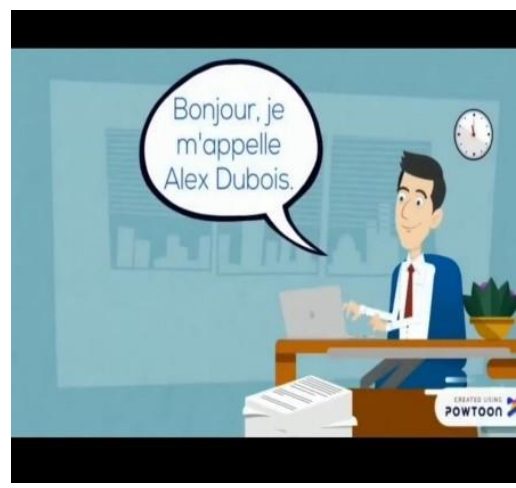

Fig. 4. Animated Film.

A study on the use of Instagram in order to increase student writing using images has shown that the use of photographs on Instagram has enhanced the skills of students to write descriptive texts[11].

Listening activities. The teacher can do listening learning activities, such as uploading a French song, animated movie or a short Instagram chat to the teacher. Students must next observe and heard the song's sub-stance, answer a number of questions on the animation film topic, or respond to various questions on the dialog's content.

Instagram is a useful tool for language teaching from the previous exercises. It offers many ad-vantages in some ways. Firstly, it can help strengthen communication skills and provide a "back door" to shy students. Although a huge proportion of students struggle to talk to their other pupils, they can feel better at Instagram. Secondly, Instagram uses the written word to boost writing skills. Third, Instagram encourages kids to cooperate and take input from their peers. Fourth, Instagram im-proves kids' interpersonal skills. Instagram boosts the interpersonal abilities of students, fourthly. This instrument allows teachers to involve students in classroom work utilizing interpersonal skills to understand the feelings and emotions of their students. Finally, this online tool invites teachers and students to participate on a single platform in a number of enjoyable activities and engagements.

\section{Method}

Research and development in education is a process used to develop and validate educational products, such as teaching materials or learning media. 
This model was developed systematically referring to the theoretical foundation of the developed learning design. This model is programmed with systematic sequences of activities. to solve learning problems related to learning media according to the needs and characteristics of students.

\section{Results and Discussion}

In this article, the research data that can be explained is the data from the questionnaire analysis of student needs. A needs analysis was conducted to determine students' interest in media in internet-based learning. This is done to find out and clarify problems that occur during the teaching and learning process and improve learning media. At the stage of needs, analysis is a necessary step to determine the internet-based learning media that is appropriate and by the needs of class X high school students in teaching French subjects.

A needs analysis questionnaire was given to 145 students of class X Senior High School by using google form. Based on the results of the questionnaire answers, the students' needs analysis showed that 1) $94 \%$ of students stated that French needs to be studied in Senior High School/Vocational High School, 2) $97.2 \%$ teaching French subjects must use interesting learning media, 3) $75.2 \%$ internet-based learning media is more interesting than other learning media such as adobe flash, PowerPoint, image media, 4) $97.2 \%$ of students know about social media Instagram, 5) $6 \%$ students obtain information about social media Instagram from teachers, $23.2 \%$ from friends, $68 \%$ from the internet, 6) $77.2 \%$ of students answered that Instagram media can be used as a learning medium for teaching French in Senior High School/Vocational High School, and 7) $79 \%$ of students answered that teaching French by using Instagram media can motivate students to improve their French language skills.

According to the data above, in general, students need innovative and interesting internetbased learning media to motivate them to learn French in Senior High School/Vocational High School. So that the French language skills (listening, speaking, reading, writing) of students can increase.

\section{Conclusion}

After discussing Instagram and the activities of Instagram, it could be determined that Instagram will improve the linguistic ability of students. It is a valuable educational tool in which students and teachers may communicate easily over the workplace and school hours. Using Instagram, students can produce ideas that are contextually relevant and provide them with a learning experience they like. Consequently, teachers can use Instagram to interestingly create some activities in French edu-cation. Finally, it can be stressed that the use of Instagram in foreign language instruction is an effi-cient tool because students and teachers use it responsibly for educational purposes.

\section{References}

[1] Darmawan D. Pengembangan E-Learning Teori dan Desain. Bandung: PT Remaja Rosdakarya; 2014. 15. 
[2] Henderson AJ. The E-Learning Question and Answer Book. New York: American Management Association Inc; 2003. 1.

[3] Nasrullah R. Media Sosial. Bandung: Simbiosa Rekatama Media; 2015. 3.

[4] Kemendikbud. Peraturan Menteri Pendidikan Dan Kebudayaan Republik Indonesia Nomor 37 Tahun 2018: Perubahan Atas Peraturan Menteri Pendidikan Dan Kebudayaan Nomor 24 Tahun 2016 Tentang Kompetensi Inti Dan Kompetensi Dasar Pelajaran Pada Kurikulum 2013 Pada Pendidikan Dasar Dan Pendidikan Menengah. Indonesia: Menteri Pendidikan dan Kebudayaan Republik Indonesia; 2018. 496-497.

[5] Hudson H. 10 ways to use Instagram in the classroom. Available from: http://www.weareteachers.com/comunity/blogs/ [Accessed 20 $0^{\text {th }}$ March 2017].

[6] Mason R. Learning Technologies for adult Continuing Education. Studies incontinuing Edu. 2006; 28(2):121-133.

[7] Lindani AR. Potensi Pemanfaatan Media Sosial Instagram Sebagai Media Pembelajaran Untuk Siswa Sekolah Menengah Atas. Salatiga: Universitas Kristen Satya Wacana; 2016. 1-28.

[8] Vie S. Digital divide 2.0: "Generation M" and online social networking sites in the composition classroom. Computers and Composition. 2008; 25(1):9-23.

[9] Bell MA. Picture this! Using Instagram with students. Internet@ Schools. 2013; 20(4):23-25.

[10] Handayani F. Instagram As A Teaching Tool? Really? Proceeding of the Fourth International Seminar on English Language and Teaching (ISELT-4); $11^{\text {th }}-12^{\text {th }}$ May 2016; Padang. 2016. p. 320327.

[11] Purwandari M. The Use of Photographs on Instagram in Teaching Descriptive Text to Improve Students' Writing skill. J Eng Lang Teaching. 2017; 6(2):133-141. 